Check for updates

Cite this: RSC Adv., 2020, 10, 21350

Received 23rd February 2020

Accepted 16th March 2020

DOI: $10.1039 /$ dOra01734e

rsc.li/rsc-advances

\section{Tested functionalization of alginate-immobilized ureolytic bacteria for improvement of soil biocementation and maximizing water retention}

\begin{abstract}
Tarek H. Taha, ${ }^{a}$ Mohamed S. Elnouby, (D) ${ }^{b}$ M. A. Abu-Saied (D) *c and Saad Alamride
The future expected water scarcity in the world invites the scientists to figure out sustainable solutions for agriculture needs. One of suggested solutions could be the improvement of soil stability and increasing its water retention ability. The current proposal is concerning by the improvement of soil stability through biocementation process. While, water retention ability was enhanced through the amendment of tested soils with alginate hydrogel. An ureolytic bacterial isolate showed a detectable ability to dissociate urea and act as a nucleation site for calcium carbonate precipitation. The bacterium was identified as Bacillus sp. after comparing with other strains in GenBank. The mechanical properties of three tested soil types (sand, calcareous, and clay) were improved after the biocementation by calcium carbonate from 119.8, 45.9, and 5 (N) to 187.5, 423.9, and 337.2, respectively. The Energy-dispersive X-ray spectroscopy (EDX) analysis confirmed the appearance of carbon element in samples containing bacterial-immobilized beads and free bacterial cells indicating calcium carbonate formation. The water uptake measurements investigated the ability of alginate beads to retain water with a percentage of $55 \%$. The overall results prove the capability of Bacillus sp. strain combined with alginate hydrogel to improve the soil stability and water retention ability.
\end{abstract}

\section{Introduction}

Microbially induced calcite precipitation (MICP) has recently gained much attention due to its versatility and sustainable applications. $^{\mathbf{1 , 2}}$ It is a natural process that involves in situ cementation component known as calcium carbonate or calcite. It can be occurred by different methods; however, the microbial one is the most interesting one that involves the bacterial metabolic transformation of urea into ammonium $\left(\mathrm{NH}_{4}^{+}\right)$and carbonate $\left(\mathrm{CO}_{3}{ }^{2-}\right)$ ions through the production of urease enzyme. In the presence of calcium ions, the liberated carbonate ions can chemically bind to calcium ions forming calcite structure between the soil particles increasing its

${ }^{a}$ Environmental Biotechnology Department, Genetic Engineering and Biotechnology Research Institute (GEBRI), City of Scientific Research and Technological Applications (SRTA-City), New Borg El-Arab City, 21934, Alexandria, Egypt

${ }^{b}$ Composite and Nanostructured Materials Research Department, Advanced Technology and New Materials Research Institute, City of Scientific Research and Technological Applications (SRTA-City), New Borg El-Arab City, 21934, Alexandria, Egypt

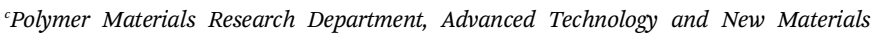
Research Institute, City of Scientific Research and Technological Applications (SRTACity), New Borg El-Arab City, 21934, Alexandria, Egypt.E-mail: maabusaied@srtacity. sci.eg; mouhamedabdelrehem@yahoo.com; Fax: +203 4593423; Tel: +201004262356

${ }^{d}$ Department of Biology, College of Science, King Khalid University, P. O. Box 9004, Abha, Saudi Arabia

${ }^{e}$ Research Center for Advanced Materials Science (RCAMS), King Khalid University, P. O. Box 9004, Abha 61413, Saudi Arabia strength and stability. ${ }^{3}$ The whole process can be followed through the following equations:

$$
\begin{gathered}
\mathrm{CO}\left(\mathrm{NH}_{2}\right)_{2}+\mathrm{H}_{2} \mathrm{O} \rightarrow 2 \mathrm{NH}_{4}^{+}+\mathrm{CO}_{3}^{2-} \\
\mathrm{Ca}^{2+}+\mathrm{CO}_{3}^{2-} \rightarrow \mathrm{CaCO}_{3}(\mathrm{~s}) \downarrow
\end{gathered}
$$

Soil precipitated calcium carbonate can improve the quality of poor soil, such as; sandy soil and organic soil. Canakci and his colleagues studied the effect of bacterial calcium carbonate precipitation on compressibility and shear strength of organic soil. ${ }^{4,5}$ In general, the precipitation of calcite into different soil types resulted in soil mechanical improvements. ${ }^{3}$

Biomaterials is suitable for applications of agriculture, potentially alginate is including in it. It is composed of 1-4linked L-guluronic acid (G units) and D-mannuronic acid (M units) which sequentially distributed along the polymer chain and vary in proportion. Alginate is considered a biocompatible material of natural origin. ${ }^{6}$ It is able to form hydrogels in the presence of multivalent cations (i.e., $\mathrm{Ca}^{2+}$ ) through the ionic interaction between the carboxylic acid group located on the polymer backbone and the chelating cation. ${ }^{7}$ Calcium crosslinked alginate hydrogels have been used in many agricultural applications. In a typically way alginate is used in the hydrogel in a physical form with small pores ( $\mathrm{nm}$ size scale) that do not allow for cell movement out or in the material. ${ }^{8}$

This work aims to improve the mechanical stability and strength of different soil types through MICP technique and 
increasing the ability of these soils to hold water through the existence of hydrogel polymers such as alginate. The isolation of ureolytic bacteria, detection and characterization of the formed calcium carbonate material, detection of the soil stability after calcite precipitation, and the water uptake capacity of the alginate hydrogel were investigated.

\section{Materials and methods}

\section{Sample preparation}

Soil sample was collected form Borg Al_arab city and was used for the isolation of urease producing bacteria. One gram of the soil was serially diluted $\left(10^{-1}\right.$ to $\left.10^{-7}\right)$ using sterile distilled water.

\section{Media}

- Urea agar base media (Christensen's medium) was used for the detection of urease activity and was composed of $\left(\mathrm{g} \mathrm{L}^{-1}\right)$ : peptone, 1.0; glucose, 1.0; sodium chloride 5.0; disodium phosphate, 1.2; potassium dihydrogen phosphate, 0.8 ; phenol red 0.012; and agar $15.0(\mathrm{pH} 6.8 \pm 0.2)$. The medium was sterilized through autoclaving at $15 \mathrm{psi}$ and $115{ }^{\circ} \mathrm{C}$ for $20 \mathrm{~min}$. After cooling to $50{ }^{\circ} \mathrm{C}, 5 \mathrm{ml}$ of filter sterilized urea (40\%) was aseptically mixed with $95 \mathrm{ml}$ of the mentioned media. All components were mixed well and distributed into sterile Petri plates.

- Luria-Bertani (LB) media was used for enrichment or overnight cultivation of the bacterial strains and composed of $(\mathrm{g}$ $\mathrm{L}^{-1}$ ): yeast extract, 5; peptone, 10; and sodium chloride, 10 for broth cultures, with the addition of 15 grams agar for solid medium preparations.

\section{Isolation of urease producing bacteria}

Twenty-five microliters of each dilution of the soil sample was spread over urea agar plates and was loaded using sterile glass spreader. The plates were incubated at $30{ }^{\circ} \mathrm{C}$ for $72 \mathrm{~h}$. The urease producing bacteria were characterized through the transformation of the color of the agar from yellow to pink. The pink color formed bacterial isolates were picked up and transferred to LB agar plates for purification. After purification, a pure single colony of each selected bacterial isolate was transferred to a tube containing $5 \mathrm{ml} \mathrm{LB}$ broth and was incubated at $30^{\circ} \mathrm{C}$ and $150 \mathrm{rpm}$ for $24 \mathrm{~h}$. A volume of $750 \mu \mathrm{l}$ of each culture was mixed with $250 \mu \mathrm{l}$ of sterile glycerol (60\%) and was kept at $-20{ }^{\circ} \mathrm{C}$ for long run preservation.

\section{Bacterial immobilization}

The alginate polymeric material was used for both purposes of bacterial immobilization and water retention as a hydrogel representative polymer. Sodium alginate $(1 \%)$ was dissolved in distilled water through boiling with stirring for $15 \mathrm{~min}$. After cooling, each 10 grams of the alginate solution were mixed with $20 \mathrm{ml}$ of free bacterial cells $\left(\mathrm{OD}_{600}\right.$ 1.0) for the preparation of bacterialimmobilized capsules. Both of alginate containing bacteria and alginate free were wisely dropped into calcium chloride solution $(3.5 \%)$ as a cross linker. The formed capsules were stirred in the solution for 15 min till complete solidification. All capsules were

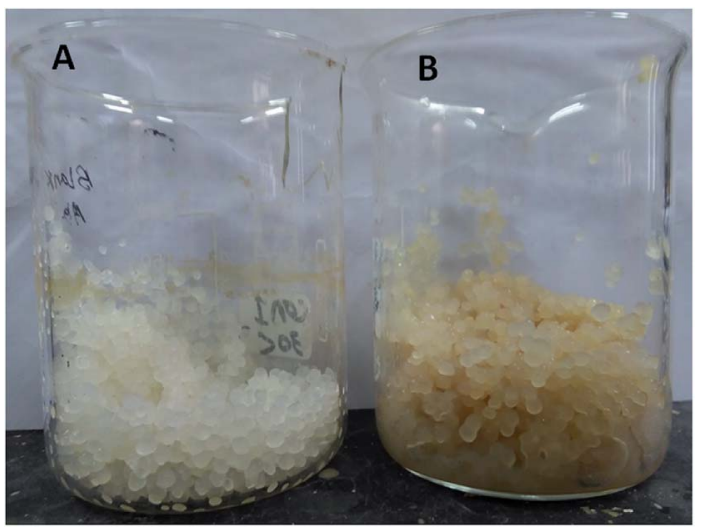

Fig. 1 Calcium alginate beads (A) without bacteria, and (B) with bacteria.

then washed with sterile distilled water for removing of excess bacteria and calcium ions. Both of alginate capsules with and without bacterial cells are shown in Fig. 1.

\section{Experimental design}

The biocementation process was tested on three soil types including calcareous soil, clay soil and sand soil. The design was performed in triplicates and started by weighing of 100 grams of each soil sample in separate glass containers. The first group of containers included the three soil samples separately amended with 10 grams of immobilized bacterial cells (capsules), and 10 grams of bacterial-free alginate capsules for control containers. While, the second group of containers included $20 \mathrm{ml}\left(\mathrm{OD}_{600}\right.$ 1.0) of free bacterial cells in LB broth for test containers, and $20 \mathrm{ml}$ distilled water for un-inoculated containers as control.

A mixed urea and calcium ions solution $(200 \mathrm{mM}$ urea, $100 \mathrm{mM} \mathrm{CaCl}_{2} \cdot 2 \mathrm{H}_{2} \mathrm{O}$, and $0.5 \mathrm{~g} \mathrm{~L}^{-1} \mathrm{LB}$ ) was prepared and $20 \mathrm{ml}$ were amended to all containers including controls. All containers were kept at room temperature under static conditions for three days. All samples were subsequently submitted for instrumental characterization and investigation of calcium carbonate formation. The glass containers containing soil samples with bacterial-free beads, bacterial-immobilized beads, and free bacterial cells are shown in Fig. 2 .

\section{Molecular identification of the bacterial isolate}

DNA extraction. The genomic DNA of the bacterial isolate was extracted using Amshag kit (SRTA-City, Egypt) according to the instructions' manual.

PCR amplification of 16S rRNA gene. The genomic DNA was used as a template for the amplification of $16 \mathrm{~S}$ rRNA gene using universal primers. The PCR components consisted of $12.5 \mu \mathrm{l}$ of PCR master mix (TAKARA, Japan), $1 \mu \mathrm{l}$ of the forward primer $\left(5^{\prime}\right.$ AACTGGAGGAAGGTGGGGAT- $\left.3^{\prime}\right), 1 \mu \mathrm{l}$ of the reverse primer $\left(5^{\prime}\right.$ AGGAGGTGATCCAACCGCA- $3^{\prime}$ ), $1 \mu \mathrm{l}$ of the genomic DNA, and sterile injection water up to $25 \mu \mathrm{l}$. The PCR program consisted of an initial step at $94{ }^{\circ} \mathrm{C}$ for $5 \mathrm{~min}$, followed by 30 cycles of denaturation at $94{ }^{\circ} \mathrm{C}$ for $1 \mathrm{~min}$, annealing at $55{ }^{\circ} \mathrm{C}$ for $1 \mathrm{~min}$, 


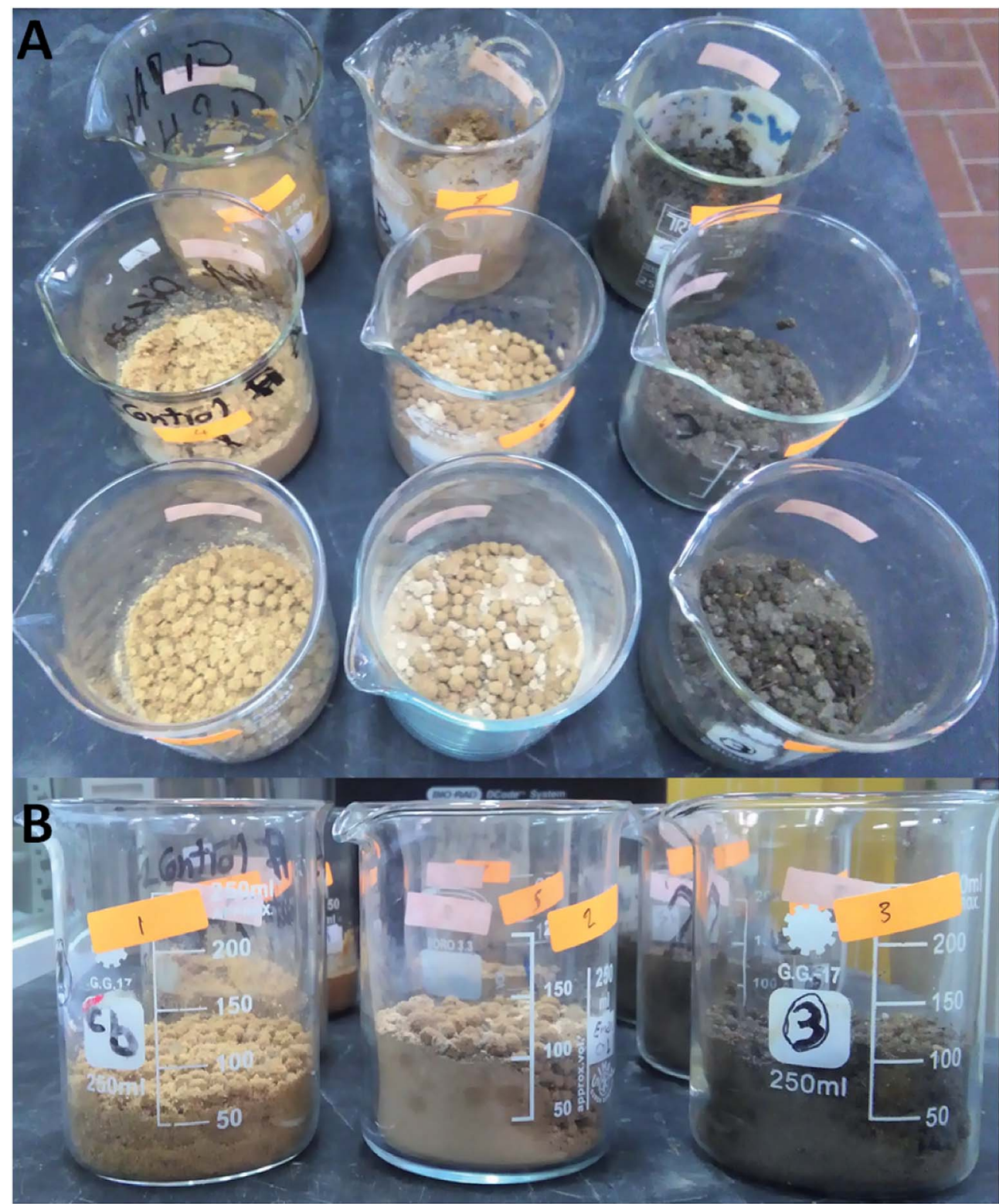

Fig. 2 Beakers of the mixed three tested soil samples with bacterial-free beads, bacterial-immobilized beads, and free bacterial cells; (A): upper view, and (B): side view.

and extension at $72{ }^{\circ} \mathrm{C}$ for $1 \mathrm{~min}$. The cycles were followed by a final extension step at $72{ }^{\circ} \mathrm{C}$ for $7 \mathrm{~min}$. The PCR product was checked through the migration in $1 \%$ agarose gel for $20 \mathrm{~min}$ at $120 \mathrm{~V}$ using $1 \times$ TBE as a running buffer. The successful amplification of the gene was investigated using UV transilluminator and was photographed using Gel documentation machine.

Sequence similarities and phylogenetic analysis. The amplified gene was sequenced (Sigma, Germany), and the obtained sequence was compared with deposited sequences in GenBank (http://www.ncbi.nlm.gov/blast). The sequence was deposited in GenBank with a new accession number and the alignment and phylogenetic analysis of the obtained sequence and other similar sequences were performed using MEGA 5.1 program.

\section{Characterization}

Scanning electron microscopy and energy dispersive X-ray spectroscopy (EDX). Scanning electron microscope (SEM) was used to investigate the surface and the morphological structure of the prepared samples using a (JSM 6360 LA, JEOL, Japan), at an accelerating voltage of $20 \mathrm{KV}$. The elemental analysis of all samples in addition the three blank soil samples was detected using energy dispersive X-ray spectroscopy (EDX) at acceleration volt of $15 \mathrm{KV}$.

Mechanical properties (compression test). The compression test of all samples was investigated using the Universal Testing Machine (Shimadzu UTM, Japan). Measurements were performed at room temperature and carried out at constant speed of cross heads of $5 \mathrm{~mm} \mathrm{~min}{ }^{-1}$. 
X-Ray diffraction (XRD). The crystalline structures of two control and free bacterial cells-containing soil samples were examined using X-ray diffraction (XRD, Shimadzu, 400, Japan).

Water uptake. Beads specimens (bacterial-free beads and bacterial-immobilized beads) were immersed in deionized water at room temperature for $24 \mathrm{~h}$ and were then picked up out of the water. The water on the beads surfaces was removed by wiping with filter paper and the samples were weighed immediately. Water uptake was calculated from the following equation;

$$
W \%=\frac{W_{\text {wet }}-W_{\text {dry }}}{W_{\text {dry }}} \times 100
$$

where, $W_{\text {wet }}$ and $W_{\text {dry }}$ were the weights of the wet and dry beads, respectively.

\section{Results}

\section{Isolation of urease producing bacteria}

A serially diluted soil sample was used for the isolation of urease producing bacteria using urea agar base. A pink color spot surrounded by a yellow color of the urea agar base plate was observed after three days of incubation (Fig. 3). The bacterial isolates that were existed inside the pink color spot were purified on LB agar plates using streaking method. Each bacterial isolate was re-inoculated onto urea agar base agar. A single bacterial colony showed an observable ability to transform the yellow color of the agar into pink color. The colony was submitted for DNA extraction and PCR amplification of $16 \mathrm{~S}$ rRNA gene for molecular identification.

\section{Molecular identification of the bacterial isolate}

The identification of the bacterial isolate was depending on PCR amplification of $16 \mathrm{~S}$ rRNA gene using universal primers. The primers succeeded to amplify $350 \mathrm{bp}$ of the targeted gene as detected by gel documentation system. The amplified gene was

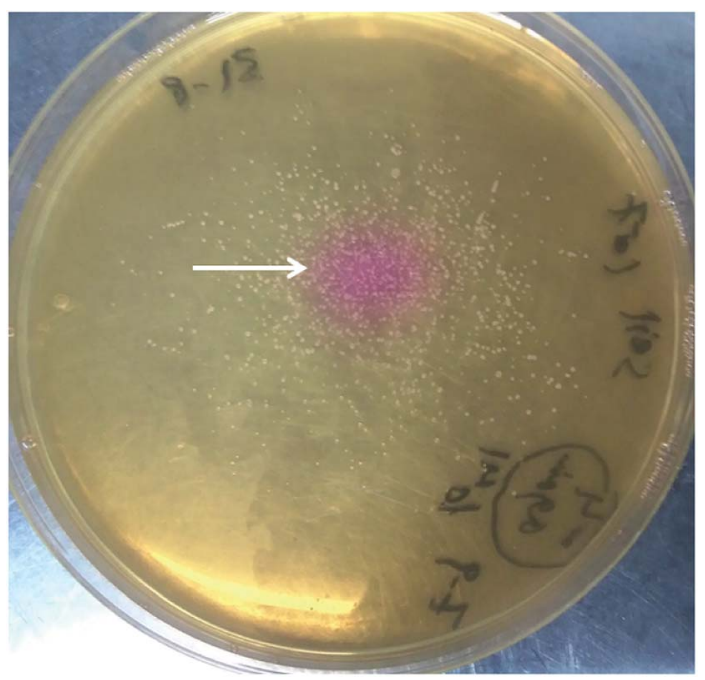

Fig. 3 Christensen's agar media indicates the ability of soil bacteria to change the color of the medium from yellow to pink (as shown by the white arrow) proving the ureolytic activity. submitted to sequencing (Sigma, Germany). The obtained sequence was compared with the GenBank' deposited sequences and revealed that the isolate is almost Bacillus sp. with 99\% similarity. Soundharya and Nirmal mentioned that Bacillus isolates are common soil bacteria that able to precipitate calcite under specific conditions. ${ }^{9}$ The obtained sequence was deposited in GenBank with the accession number MN658516. The phylogenetic relationship of the isolate Bacillus sp. and other similar strains can be shown in Fig. 4 .

\section{Mechanical properties (compression test)}

The mechanical strength of the blank beads, bacterialimmobilized beads, and free bacterial cells in all tested soil samples were analyzed by compression testing. The maximum force $(\mathrm{N})$ of each sample was calculated at the breakdown point. Table 1 shows increasing the max force $(\mathrm{N})$ from 45.8 for control calcareous soil-beads to 180.3 with bacterial-immobilized calcareous soil to reach the maximum increment at 423.4 with tested calcareous soil amended with free bacteria. On the other hand, the max force $(\mathrm{N})$ was increased from 5 with control clay soil amended with blank beads to 215.5 with tested clay soil amended with bacterial-immobilized beads to reach the maximum increment at 337.2 with test clay soil amended with free bacteria. The same observation was also detected for sand samples.

\section{Soil structural analysis}

EDX. The basic concept of the current experiment is depending on the dissociation of urea into carbon dioxide and ammonia through the ureolytic activity of the bacterial isolate. Under alkaline condition, the carbon dioxide will be transformed into carbonate ions which are almost combined with free calcium ions to form calcium carbonate. The confirmation of the ability of the bacterial cells to form calcium carbonate crystals is almost detected through the existence of calcium, carbon and oxygen elements as related to the mass percentage of the three elements in $\mathrm{CaCO}_{3}$. This detection is almost analyzed using EDX analysis.

As shown in Table 2, calcareous soil containing bacterialimmobilized beads showed mass percentages of 20.5, 10.49, and 41.38 for calcium, carbon, and oxygen elements, respectively. While, the mass percentages of calcium, carbon, and oxygen were $19.31,9.48$, and 41.74 , for calcareous soil containing free bacterial cells, respectively. These two samples were showed as the highest percentages of formed calcium carbonate crystals. In case of clay soil type, the mass percentages for calcium, carbon, and oxygen were 5.12, 16.7, and 39.29 for bacterial-immobilized beads, respectively. In same soil type that lake the polymeric beads, the mass percentages for calcium, carbon, and oxygen were $4.97,18.10$, and 33.39, respectively. These two samples were showed as the moderate percentages for the formation of calcium carbonate crystals.

Moreover, the sand samples that contain free bacterial cells showed mass percentages of $3.83,14.34$, and 34.41 for calcium, carbon, and oxygen, respectively. This sample showed the lowest percentage of formed calcium carbonate crystals. On the 


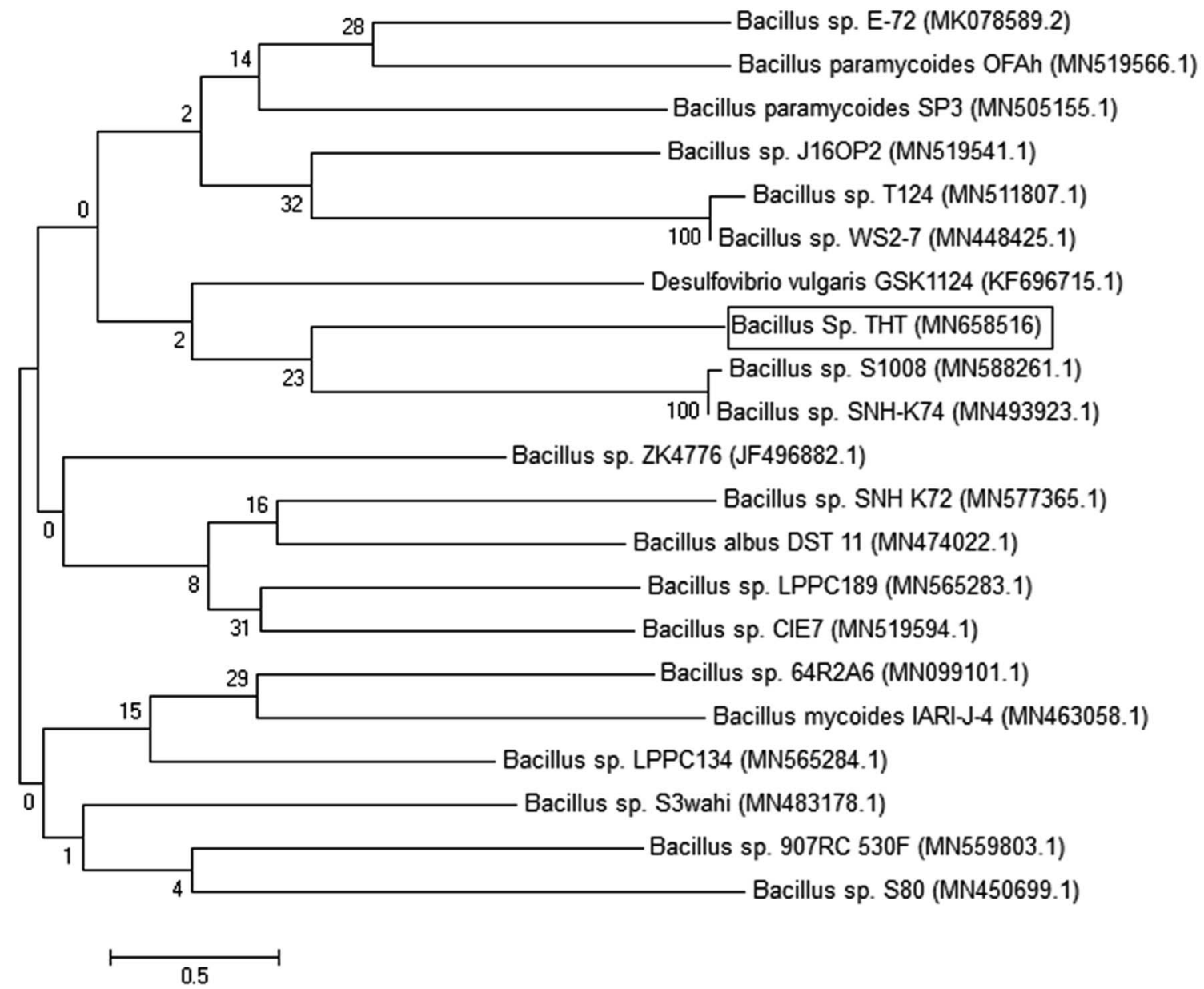

Fig. 4 Phylogenetic position of Bacillus sp. THT with similar sequences of the same genus. The branching pattern was generated by neighborjoining tree method with 500 bootstrap and the Genbank accession numbers of the 16S rRNA nucleotide sequences are indicated in brackets.

other hand, all control samples in addition to sand sample that contains bacterial-immobilized beads failed to form calcium carbonate crystals as detected by EDX analysis (Table 2). As shown in Table 3, the EDX analysis of the three blank soil samples demonstrates that, the Si element is dominating in sand soil, while Ca element is dominating in calcareous soil. Moreover, $\mathrm{C}$ element was detected as the dominating element in clay soil. On the other hand all, the other detected elements $(\mathrm{O}$, $\mathrm{Na}, \mathrm{Mg}, \mathrm{Cl}, \mathrm{Al}, \mathrm{K}$, and $\mathrm{Fe}$ ) we almost in the same percentage in the three tested soil samples. It worth mentioning that the EDX spots of the scanned materials can be seen as white circles as shown in Fig. 6. In addition, the EDX results mentioned in Table 2 are the mean readings of several spots inside the white circle of Fig. 6.

XRD. XRD characterization technique was used to confirm the precipitation of calcium carbonate in bacterial existed samples. Fig. 5 presented the XRD patterns of soil before and after bacterial and nutrients amendments. The main peak in all XRD patterns at 26.7 is referring to silicate $\left(\mathrm{SiO}_{2}, \mathrm{ICDD}\right.$ card no. 00-046-1045). Fig. 5a shows the XRD pattern of the soil before bacterial and nutrients amendments. The peaks around (36.7, $51.9,67.8)$ refer to calcium oxide (CaO, ICDD card no. 01-0704068). While, Fig. $5 \mathrm{~b}$ shows the XRD pattern of the clay soil after bacterial and nutrients amendments. Moreover, the peaks around $(29.4,39.5$, and 60.4$)$ refer to calcite structure of calcium carbonate $\left(\mathrm{CaCO}_{3}\right.$, ICDD card no. 00-003-0596). These results are in a good agreement with the previous EDX results (Table 2), where the $\mathrm{CaO}$ was appeared strongly after bacterial treatment. On the other hand, the mechanical properties are also compacted with these findings (Table 1).

Water uptake of beads. Both of bacterial-free beads and bacterial-immobilized beads were tested for their ability to retain water molecules. The obtained data revealed that the percentage of water uptake was $55.55 \%$ for bacterial-free beads compared with $42.85 \%$ for bacterial-immobilized beads.

Scanning electron microscope (SEM). The morphological structure of soil particles was studied using SEM technique. Fig. 6 micrograph shows the morphological changes of the soil before and after amendment of bacteria and cementation solution. It is almost common for the three tested soil samples that the particles are somehow distributed and un-integrated (Fig. 6a, c, and e). However, the existence of bacterial strain improves the appearance of aggregated soil particles as indicated by the white arrows (Fig. 6b, d, and f). 
Table 1 Mechanical properties for the three tested soil types in absence or co-existence of bacterial cells and polymeric beads ${ }^{a}$

\begin{tabular}{|c|c|c|}
\hline Sample & Max force (N) & Max disp. (mm) \\
\hline $\begin{array}{l}\text { Sand sample amended with alginate beads } \\
\text { (control) }\end{array}$ & 119.8 & 10.13 \\
\hline $\begin{array}{l}\text { calcareous soil sample amended with } \\
\text { alginate beads (control) }\end{array}$ & 45.8 & 20.40 \\
\hline $\begin{array}{l}\text { Clay soil sample amended with alginate } \\
\text { beads (control) }\end{array}$ & 5.0 & 15.96 \\
\hline $\begin{array}{l}\text { Sand sample amended with bacterial- } \\
\text { immobilized beads }\end{array}$ & - & - \\
\hline $\begin{array}{l}\text { Calcareous soil sample amended with } \\
\text { bacterial-immobilized beads }\end{array}$ & 180.3 & 18.38 \\
\hline $\begin{array}{l}\text { Clay soil sample amended with bacterial- } \\
\text { immobilized beads }\end{array}$ & 215.5 & 17.93 \\
\hline $\begin{array}{l}\text { Sand sample amended with free bacterial } \\
\text { cells }\end{array}$ & 187.5 & 11.02 \\
\hline $\begin{array}{l}\text { Calcareous soil sample amended with free } \\
\text { bacterial cells }\end{array}$ & 423.4 & 23.4 \\
\hline $\begin{array}{l}\text { Clay soil sample amended with free } \\
\text { bacterial cells }\end{array}$ & 337.2 & 20.97 \\
\hline
\end{tabular}

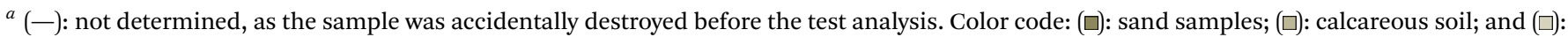
clay soil.

\section{Discussion}

Microbially induced calcite precipitation (MICP) has recently gained much attention due to its versatility and sustainability especially for geotechnical engineering and soil interested researchers. ${ }^{1}$ The current used soil improvement techniques such as using of cement and chemical additions needs much amounts of energy and man-made materials. However, MICP technique can provide low-energy inputs, non-pathogenic microbe, in addition to being eco-friendly. ${ }^{3}$

In current study, urease producing bacteria was isolated from soil and showed the ability to convert the yellow color of the indicator of the urea agar base media into pink (Fig. 3). The molecular identification of the isolate showed that it belongs to the genus Bacillus and has been deposited in GenBank with the accession number MN658516. Qian and his colleagues mentioned that the biocementation process in the form of precipitated calcium carbonate is always accompanied by bacterial activity in a system rich with calcium ions. ${ }^{10}$ It is basically depending on the application of urease-producing microorganisms in the presence of urea and calcium ions in a permeable soil. ${ }^{11,12}$

One of the tests that can detect the effect of the precipitated calcite on the mechanical stability of soil is compression test. As shown in Table 1, the maximum force for the tested soil samples was varied according to the absence or presence of alginate beads. However, the three tested soil types share the same observation which can be presented as: free bacterial cells $>$ bacterial-immobilized beads > bacterial-free beads. However, the alginate beads itself have an enhanced mechanical properties. ${ }^{13}$

These results would be attributed to the ability of free bacterial cells to act as a nucleation site for the precipitation of the produced calcium carbonate crystals, which would increase the homogeneity and attachment of soil particles together. Previous studies mentioned that the presence of nucleation site like bacterial cells is very important for the homogeneity and strength of the produced carbonate. ${ }^{14,15}$

However, the bacterial-immobilized beads revealed the deposition of calcium carbonate crystals around the bacterial cells and the beads, which in turn showed some kind of soil 
Table 2 The elemental analysis of the tested soil samples ${ }^{a}$

\begin{tabular}{|c|c|c|c|c|c|c|c|c|}
\hline $\begin{array}{c}\text { Sample } \\
\text { Sand sample amended with } \\
\text { alginate beads (control) }\end{array}$ & - & 0.02 & 16.71 & 44.3 & 2.7 & 2.27 & 33.79 & - \\
\hline $\begin{array}{c}\text { Calcareous soil sample } \\
\text { amended with alginate beads } \\
\text { (control) }\end{array}$ & - & 1.05 & 26.86 & 30.01 & 3.32 & 20.28 & 18.48 & - \\
\hline $\begin{array}{c}\text { Clay soil sample amended } \\
\text { with alginate beads (control) }\end{array}$ & - & 1.56 & 19.22 & 33.33 & 3.38 & 14.59 & 27.79 & - \\
\hline $\begin{array}{c}\text { Sand sample amended with } \\
\text { bacterial-immobilized beads }\end{array}$ & - & 2.63 & 28.05 & 23.52 & 3.08 & 27.39 & 14.56 & - \\
\hline $\begin{array}{c}\text { Calcareous soil sample } \\
\text { amended with bacterial- } \\
\text { immobilized beads }\end{array}$ & 10.49 & 20.5 & 41.38 & - & 2.7 & 17.49 & 0.65 & 5.45 \\
\hline $\begin{array}{c}\text { Clay soil sample amended } \\
\text { with bacterial-immobilized } \\
\text { beads }\end{array}$ & 16.7 & 5.12 & 39.29 & - & 2.04 & 26.95 & 0.81 & 7.04 \\
\hline $\begin{array}{c}\text { Sand sample amended with } \\
\text { free bacterial cells }\end{array}$ & 14.43 & 3.83 & 34.41 & 4.88 & 2.28 & 25.7 & 6.9 & 5.96 \\
\hline $\begin{array}{c}\text { Calcareous soil sample } \\
\text { amended with free bacterial } \\
\text { cells }\end{array}$ & 9.48 & 19.31 & 41.74 & - & 3.25 & 18.23 & 0.37 & 6.3 \\
\hline $\begin{array}{c}\text { Clay soil sample amended free bacterial cells } \\
\text { wall }\end{array}$ & 18.1 & 4.97 & 33.39 & 0.61 & 2.62 & 25.56 & 0.48 & 7.37 \\
\hline
\end{tabular}

${ }^{a}(-)$ : not detected. Color code: $(\square)$ : sand samples; $(\square)$ : calcareous soil; and (־): clay soil.

particles adhesion as a result for the formation of calcium carbonate crystals. On the other hand, the bacterial-free beads increased the gaps between soil particles and hence showed a decreased attachment of them together. It worth mentioning that soil stability was varied according to the type of soil. As shown in Table 1, the maximum force $(\mathrm{N})$ of calcareous soil was greater than clay soil followed by sand sample.
More conformational testes were provided for determination of soil structural analysis. The data obtained by EDX analysis was used to analyze the percentages of calcium, carbon and oxygen elements it the tested soil types. These elements almost reveal the bacterial formation of calcium carbonate crystals which reflect the degree of stabilization of bacterial amended soil. Table 2 shows the percentage of each element in the three

Table 3 Inorganic components of blank clay, calcareous, and sand samples

\begin{tabular}{lllllllllll}
\hline & \multicolumn{1}{l}{ Inorganic components } & & & & & \\
Soil type & $\mathrm{C}$ & $\mathrm{Ca}$ & $\mathrm{O}$ & $\mathrm{Na}$ & $\mathrm{Mg}$ & $\mathrm{Si}$ & $\mathrm{Cl}$ & $\mathrm{Al}$ & $\mathrm{K}$ \\
\hline Sand & 10.29 & 3.17 & 37.66 & 0.59 & 2.34 & 32.9 & 0.53 & 8.14 & 1.79 \\
Calcareous & 13.59 & 16.99 & 38.63 & 0.39 & 2.45 & 16.71 & 0.32 & 6.95 & 1.42 & 2.61 \\
Clay & 22.38 & 6.75 & 35.53 & 0.43 & 1.75 & 22.36 & 0.15 & 7.41 & 0.86 & 2.38
\end{tabular}




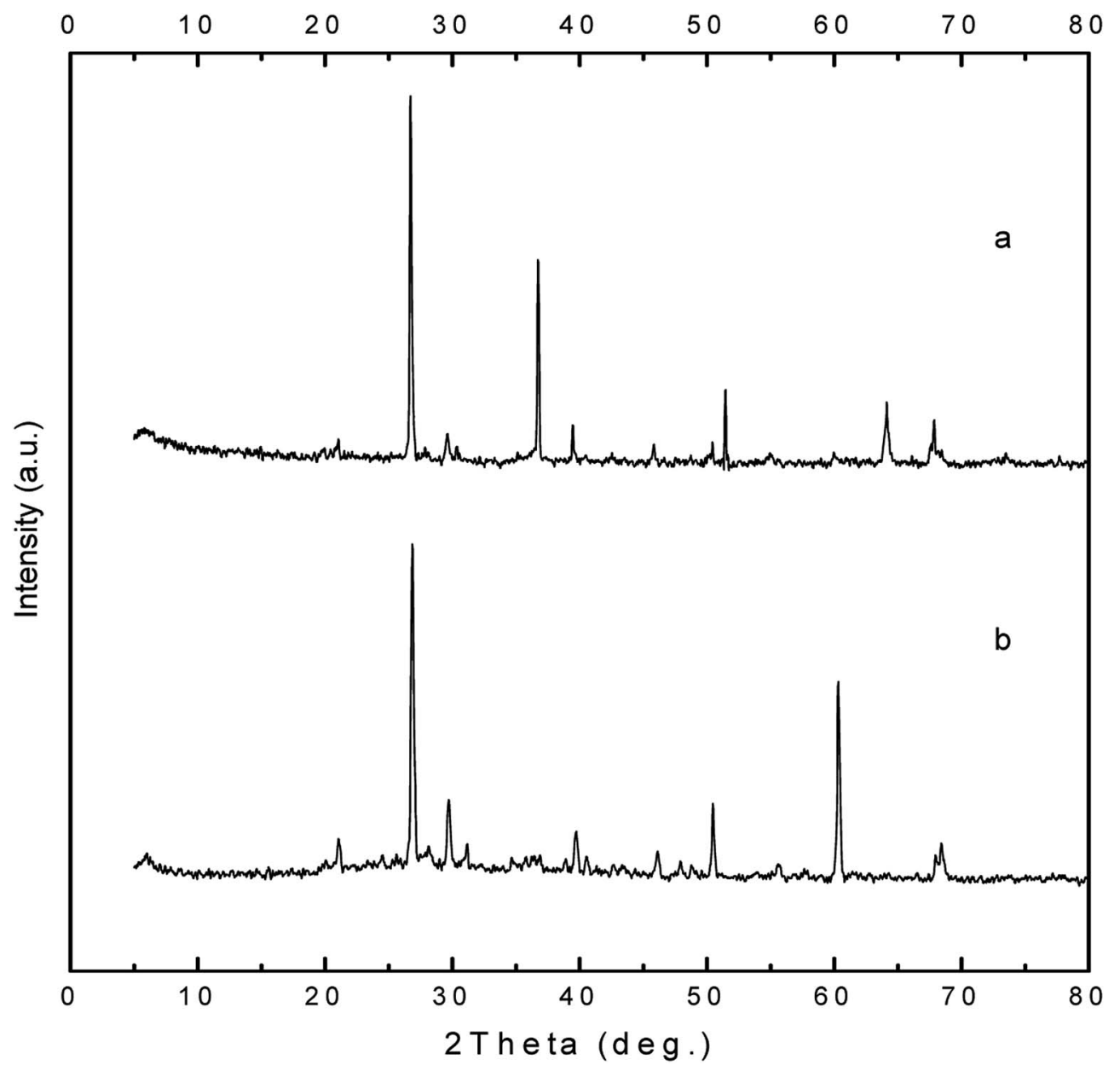

Fig. 5 XRD pattern of clay soil (a) before and (b) after bacterial and nutrients amendments.

tested soil samples (calcareous, clay, and sand). The highest percentage was recorded for calcareous soil that contains bacterial-immobilized beads with mass percentages of 20.5, 10.49 , and 41.38 for calcium, carbon, and oxygen elements, respectively. While, the lowest percentages were recorded for sand samples amended with free bacterial cells with mass percentages of $3.83,14.34$, and 34.41 for calcium, carbon, and oxygen, respectively. On the other hand, all control samples showed 0 mass percentages for the tested three elements which is perfectly matched with the results obtained by the mechanical properties (Table 1). Eventually, both of mechanical properties and EDX analysis revealed that the biocementation of soil samples is almost as follows: calcareous soil > clay soil $>$ sand sample.

XRD technique was also applied for the detection of calcite crystals by the isolated bacterial strain. It is basically used for the determination of the crystalline form of calcite crystals. ${ }^{16} \mathrm{An}$ observable peak at 26.7 that refers to silicate was detected in all XRD patterns which is matched with the concept of existence of silicate in all soil samples as investigated by EDX analysis (Table 2). Both of EDX and XRD analysis confirmed the existence of calcium carbonate, which considered a strong evidence for the microbial ureolytic activity followed by the precipitation of calcium carbonate crystals. Vahabi and his colleagues precipitated calcite structure of calcium carbonate using Bacillus licheniformis AK01 strain, as a promising alternative for sealing cement-based materials. ${ }^{17}$

On the other hand, the water retaining capacity of the alginate beads was examined. The bacterial-free beads can retain $55.55 \%$ of the amount of tested water compared with $42.85 \%$ for bacterial-immobilized beads. We could attribute the ability of bacterial-free beads to retain higher percentage of water to the existence of higher percentage of alginate polymer. However, the amount of tested alginate polymer in bacterial-immobilized beads is usually decreased and some of the polymeric material was replaced by the immobilized bacterial cells and hence reflected a lower percentage of water uptake capacity. These results are in agreement with Bajpai et al. who mentioned that the alginate polymer has higher capacity for water uptake. ${ }^{18}$

Generally, in our case, the purpose of alginateimmobilization of bacterial isolates was mainly to protect the cells in addition to exploiting the water uptake capacity of alginate hydrogel. However, other immobilization matrices were used in other experiments for other purposes. Polyurethane polymer was used to protect the bacteria from higher $\mathrm{pH}$ environments. ${ }^{19}$ In another experiment, the silica gel was 

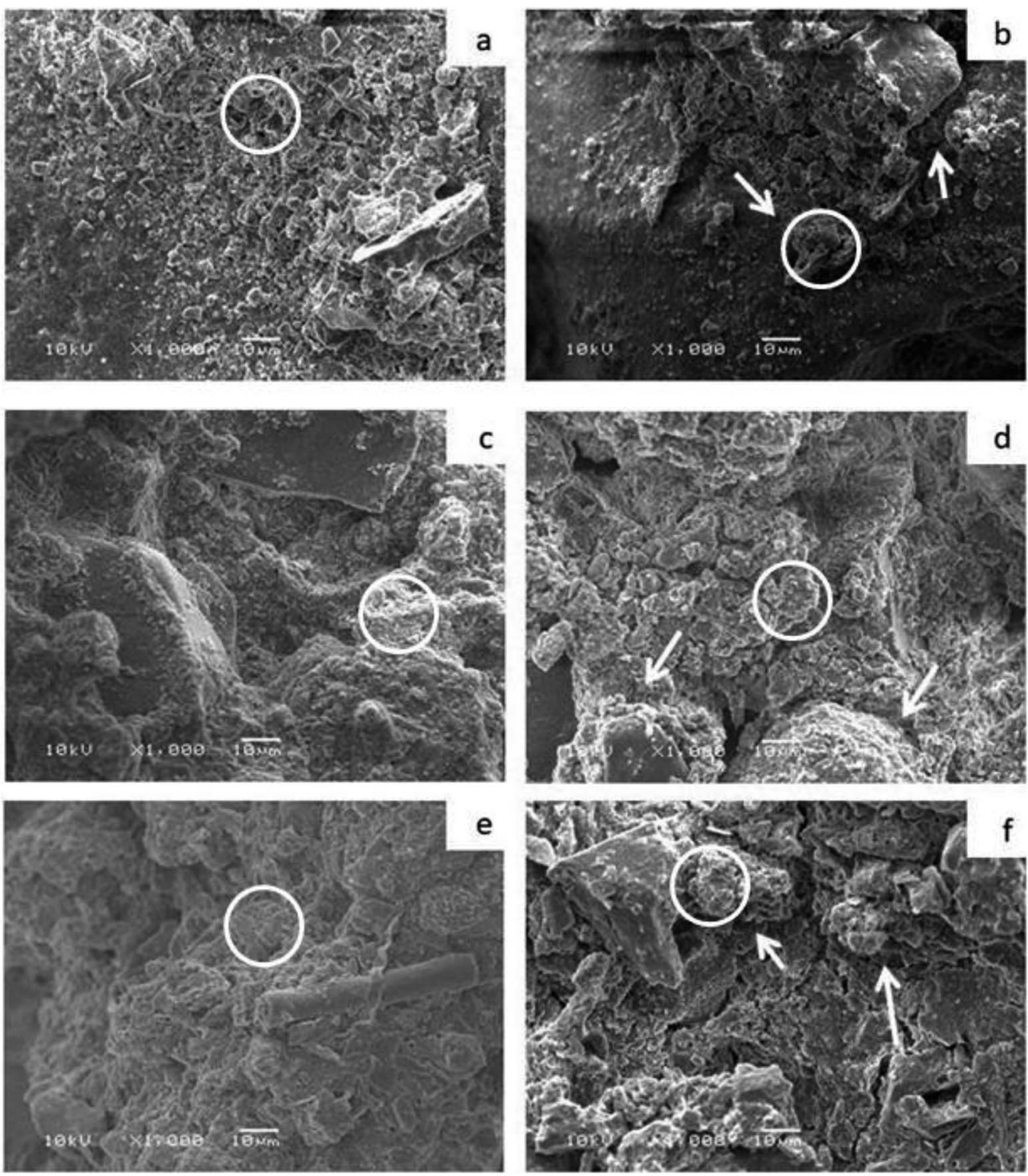

Fig. 6 SEM micrographs of tested soil samples; (a) sand sample amended with alginate beads (control), (b) calcareous soil sample amended with alginate beads (control), (c) clay soil sample amended with alginate beads (control), (d) sand sample amended with bacterial-immobilized beads, (e) calcareous soil sample amended with bacterial-immobilized beads, and (f) clay soil sample amended with bacterial-immobilized beads.

used as an immobilization matrix to be used as filling material before calcite precipitation. ${ }^{\mathbf{1 4 , 1 5 , 1 9}}$

SEM analysis is a strong and reliable evidence for the appearance of aggregated or distributed soil particles that reflect the existence or absence of calcite crystals that responsible for the aggregation process. As shown in Fig. 6, the bacterial amended soil samples were highly aggregated compared with bacterial-free soil samples. These observations investigate the existence of new structure that was not exists in bacterial-free soil samples. We could attribute the aggregation appearance of soil particles to the bacterial precipitation of calcium carbonate that enable the soil particles to adhere strongly to each other as indicated by the white arrows (Fig. 6b, $\mathrm{d}$, and f). These results are perfectly matched with the results of mechanical properties and structural analysis of soil (EDX and XRD). It would be concluded that, the isolated Bacillus sp. strain can be exploited for improving soil stability when cementation solution is added to soil. In addition, alginate polymeric material can be perfectly used for enhancement of water retention capability and considered as a promising solution for facing the upcoming water scarcity crisis.

\section{Ethics statement}

This article does not contain any studies with human participants or animals performed by any of the authors.

\section{Contributions}

TT, ME and MA Abu Saied have contributed equally in putting the idea, designing the experiments, executing the lab work and analyzing the data. SA has participated the team in the 
accomplishment of the work, revising and editing the manuscript. All authors read and approved the manuscript.

\section{Funding}

This work was support by grant number (RCAMS/KKU/002-19) from Research Center of Advanced Materials - King Khalid University, Saudi Arabia.

\section{Conflicts of interest}

All authors declares that they have no conflict of interest.

\section{References}

1 L. Cheng, M. A. Shahin and D. Mujah, Influence of key environmental conditions on microbially induced cementation for soil stabilization, J. Geotech. Geoenviron. Eng., 2016, 143(1), 04016083.

2 Z. Wang, N. Zhang, G. Cai, Y. Jin, N. Ding and D. Shen, Review of ground improvement using microbial induced carbonate precipitation (MICP), Mar. Georesour. Geotechnol., 2017, 35(8), 1135-1146.

3 K. Piriyakul, Application of Non-Destructive Testing for Measurement of Strength Development of Biocemented Sand, Adv. Mater. Res., 2013, 660-663.

4 H. Canakci, W. Sidik and I. H. Kilic, Effect of bacterial calcium carbonate precipitation on compressibility and shear strength of organic soil, Soils Found., 2015, 55(5), 1211-1221.

5 M. Aresta, Carbon dioxide utilization: The way to the circular economy, Greenhouse Gases: Sci. Technol., 2019, 9(4), 610612.

6 G. Klöck, A. Pfeffermann, C. Ryser, P. Gröhn, B. Kuttler, H.-J. Hahn, et al., Biocompatibility of mannuronic acid-rich alginates, Biomaterials, 1997, 18(10), 707-713.

7 G. T. Grant, E. R. Morris, D. A. Rees, P. J. Smith and D. Thom, Biological interactions between polysaccharides and divalent cations: the egg-box model, FEBS Lett., 1973, 32(1), 195-198.

8 P. Eiselt, J. Yeh, R. K. Latvala, L. D. Shea and D. J. Mooney, Porous carriers for biomedical applications based on alginate hydrogels, Biomaterials, 2000, 21(19), 1921-1927.
9 S. Soundharya and K. Nirmal, Strength improvement studies on self-healing characteristics of bacterial concrete, International Journal of Engineering Science Invention Research and Development, 2014, 162-164.

10 C. X. Qian, M. Luo, L. F. Ren, R. X. Wang, R. Y. Li, Q. F. Pan, et al., Self-healing and repairing concrete cracks based on bio-mineralization, Key Eng. Mater., 2015, 629, 494-503.

11 N. Chahal, R. Siddique and A. Rajor, Influence of bacteria on the compressive strength, water absorption and rapid chloride permeability of fly ash concrete, Constr. Build. Mater., 2012, 28(1), 351-356.

12 R. K. Verma, L. Chaurasia, V. Bisht and M. Thakur, Biomineralization and bacterial carbonate precipitation in mortar and concrete, Biosci. Bioeng., 2015, 1(1), 5-11.

13 M. Mancini, M. Moresi and R. Rancini, Mechanical properties of alginate gels: empirical characterisation, $J$. Food Eng., 1999, 39(4), 369-378.

14 W. De Muynck, N. De Belie and W. Verstraete, Microbial carbonate precipitation in construction materials: a review, Ecol. Eng., 2010, 36(2), 118-136.

15 W. De Muynck, K. Verbeken, N. De Belie and W. Verstraete, Influence of urea and calcium dosage on the effectiveness of bacterially induced carbonate precipitation on limestone, Ecol. Eng., 2010, 36(2), 99-111.

16 S.-J. Park, Y.-M. Park, W.-Y. Chun, W.-J. Kim and S.-Y. Ghim, Calcite-forming bacteria for compressive strength improvement in mortar, J. Microbiol. Biotechnol., 2010, 20(4), 782-788.

17 A. Vahabi, A. A. Ramezanianpour, H. Sharafi, H. S. Zahiri, H. Vali and K. A. Noghabi, Calcium carbonate precipitation by strain Bacillus licheniformis AK 01, newly isolated from loamy soil: a promising alternative for sealing cement-based materials, J. Basic Microbiol., 2015, 55(1), 105-111.

18 S. Bajpai and R. Tankhiwale, Investigation of water uptake behavior and stability of calcium alginate/chitosan bipolymeric beads: Part-1, React. Funct. Polym., 2006, 66(6), 645-658.

19 S. K. Ramachandran, V. Ramakrishnan and S. S. Bang, Remediation of concrete using micro-organisms, $A C I$ Mater. J., 2001, 98(1), 3-9. 